\title{
EFEKTIFITAS PEMBERIAN OBAT TRADISIONAL LANCAU WOLIO TERHADAP INVOLUSI UTERUS DAN ESTETIKA KECANTIKAN PADA IBU NIFAS DI KOTA BAUBAU
}

\author{
EFFECTIVENESS OF GIVING LANCAU WOLIO TOWARD UTERUS \\ INVOLUTION AND BEAUTYAESTHETIC OF POSTPARTUM \\ MOTHERSIN BAUBAU
}

\author{
Anita ${ }^{1}$,Sri Ernawati ${ }^{2}$, \\ ${ }^{1}$ Program Studi DIII Kebidanan, Politeknikbaubau \\ ${ }^{2}$ Program Studi DIII Kebidanan, Politeknikbaubau \\ "Koresponding Penulis: ${ }^{-}$anitanajwa123@gmail.com; ${ }^{2}$ sriernawati3rnai5@gmail.com
}

\begin{abstract}
ABSTRAK
Pengobatan tradisional tidak hanya digunakan sebagai obat penyembuhan penyakit infeksi, kronik, maupun akut saja tetapi juga sering digunakan dalam berbagai perawatan diantaranya adalah perawatan masa nifas, Perempuan suku Buton mempunyai tradisi pengobatan tradisional dalam perawatan masa nifas yang sering dikenal masyarakat dengan nama Lancau Wolio. Jenis penelitian desain eksperimental dengan rancangan pretest-posttest with control group. sampel dalam penelitian ini ibu nifas sebanyak 40 orang dibagi menjadi 2 kelompok, kelomok intervensi ibu yang mengonsumsi lancau wolio dan kelompok kontol ibu yang tidak mengonsumsi lancau wolio. Pemberian intervensi dilakukan selama 2 minggu. Analisa data menggunakan Uji paired t test dan uji independent $t$ test.

Hasil penelitian menunjukan ada perbedaan involusio uterus antara dua kelompok setelah 2 minggu perlakuan, dengan $p$ value $0,010<0,05$ untuk diameter uterus dengan penurunan rerata kelompok intervensi $31,70 \%$ dan kelompok kontol 40,04\% dan panjang uterus pvalue $0,004<0,05$ dengan penurunan ratarata untuk kelompok intervensi $41,37 \%$ dan kelompok control 26.16\%. dan untuk berat badan tidak ada perbedaan dengan nilai pvalue 0,812>0,05 namun terdapat penurunan sebesar 7,09 pada kelompok intervensi dan 3,52\% pada kelomok kontrol.
\end{abstract}

Kata kunci: Involusi Uterus, Estetika Kecantikan, Masa Nifas, Lancau Wolio

\section{Abstract}

Traditional medicine used not only as a cure for infectious, chronic or acute diseases. But, often used in various treatments, including postpartum care. Butonese women have a traditional medicine in postpartum care known as the Lancau Wolio. The research design was experimental and a pretest-posttest with control group design. The sample was 40 postpartum mothers and divided into 2 groups. the intervention group of mothers who consumed the Lancau Wolio and the control group of mothers who did not consume the Lancau Wolio. The intervention was carried out for 2 weeks. Data analysis used paired t test and independent $t$ test.

The results showed, there were differences in uterus involution between the two groups after 2 weeks of treatment, the uterus diameter with $p$ value $0.010<0.05$ with the average of a 
Journal of Healthcare Technology and Medicine Vol. 6 No. 2 Oktober 2020

Universitas Ubudiyah Indonesia

e-ISSN : 2615-109X

decrease in the intervention group $31.70 \%$ and a control group of $40.04 \%$ and uterus length $p$ value $0.004<0,05$ with the average of a decrease in the intervention group $41.37 \%$ and the control group $26.16 \%$. For body weight with $p$ value $t 0.812>0.05$, there was no difference but there was a decrease 7.09 in the intervention group and $3.52 \%$ in the control group.

\section{Keywords: Beauty Aesthetics, Lancau Wolio, Postpartum Period, Uterus Involution.}

\section{PENDAHULUAN}

Masa nifas adalah masa yang dimulai setelah plasenta keluar dan berakhir ketika alat alat kandungan kembali seperti keadaan semula (sebelum hamil), (Sulistiyowati, 2009:1). Dengan pemantauan yang melekat pada asuhan ibu masa nifas, maka kemungkinan kematian dapat dicegah (Prawirohardjo, 2002). Oleh karena itulah pemerintah mengeluarkan program dan kebijakan teknis, yaitu setidaknya dilakukan 4x kunjungan masa nifas untuk menilai setatus ibu dan BBL, dan untuk mencegah, mendeteksi menangani masalah-masalah yang terjadi, salah satunya masalah yang dipantau pada ibu nifas adalah involusi uteri. Involusi uteri merupakan suatu proses dimana uterus kembali kekondisi sebelum hamil dengan berat sekitar 60 gram (Ambarwati,dkk, 2009).

Pengobatan tradisional merupakan salah satu pengobatan yang masih banyak dilakukan oleh masyarakat. Menurut Badan Kesehatan Dunia (WHO), sebanyak 80\% dari total populasi di benua Asia dan Afrika bergantung pada pengobatan tradisional. WHO juga telah mengakui pengobatan tradisional dapat mengobati berbagai jenis penyakit infeksi, penyakit akut, dan penyakit kronis (Yuningsih, 2012). Sementara itu PP nomor 103 tahun 2014 menyatakan bahwa seseorang dapat dikatakan sebagai penyehat tradisional jika telah berpengalaman memberikan pelayanan kesehatan tradisional yang turun temurun secara aman dan bermanfaat selama minimal 5 tahun. Obat tradisional ini (baik berupa jamu maupun tanaman obat) masih banyak dgunakan oleh masyarakat, terutama dari kalangan menengah ke bawah dalam upaya pencegahan penyakit (preventif), penyembuhan (kuratif), pemulihan kesehatan (rehabilitatif), serta peningkatan kesehatan (promotif) (Notoatmodjo, 2013).

Pengobatan tradisional tidak hanya digunakan sebagai obat penyembuhan penyakit infeksi, kronik, maupun akut saja tetapi juga sering digunakan dalam berbagai perawatan diantaranya adalah perawatan masa nifas. Masa nifas (puerperium) yaitu dimulai setelah plasenta lahir dan berakhir ketika alat-alat kandung/an kembali seperti keadaan sebelum hamil. 
Journal of Healthcare Technology and Medicine Vol. 6 No. 2 Oktober 2020

Universitas Ubudiyah Indonesia

e-ISSN : 2615-109X

Masa nifas berlangsung kira-kira 6 minggu atau 42 hari. Asuhan masa nifas diperlukan dalam periode ini karena merupakan masa kritis baik ibu maupun bayinya (Walyani, 2015).

Berdasarkan hasil studi pendahuluan yang dilakukan oleh Mary Kristin tahun 2018 yang menyatakan bahwa salah satu ragam pengobatan tradisional Indonesia terdapat di Sulawesi Tenggara Kota Baubau Kecamatan Murhum khususnya Kelurahan Melai dan Kelurahan Baadia. Perempuan suku Buton mempunyai tradisi pengobatan tradisional dalam perawatan masa nifas yang sering dikenal masyarakat dengan nama Lancau Wolio. Lancau dalam bahasa Buton mempunyai arti obat sedangkan Wolio berarti wolio. Jika diterjemahkan secara harfiah Lancau Wolio berarti obat Wolio,yaitu suatu ramuan tradisional untuk perawatan ibu nifas. Ramuan ini sudah digunakan oleh perempuan Buton dalam masa nifas secara turun temurun sejak nenek moyang suku Buton. Lancau Wolio dibuat dengan memanfaatkan umbi, batang, dan akar dari 40 jenis tanaman, diantara beberapa tanaman yang digunakan dalam pembuatan lancau wolio, yaitu : alang-alang dan gingseng jawa yang dimanfaatkan akarnya. Kemudian kayu jawa, jarak, sambung nyawa, bangle, dan kayu kuning yang dimanfaatkan batangnya. Tanaman yang dimanfaatkan kulit batangnya, yaitu : asam jawa, jambu biji, kusambi, dan kecapi. Serta tanaman yang dimanfaatkan umbinya, yaitu ; paku uban. Seluruh bahan ini dipercaya bekhasiat mempercepat involusio uteri dan pemulihan kondisi ibu selama masa nifas meliputi peningkatan produksi ASI, mempercepat penyembuhan luka bekas implantasi plasenta di uterus maupun luka bekas jahitan perineum dan bekas operasi serta membuat tubuh ibu kembali sehat bugar dan cepat terjadi penurunan berat badan sehingga kondisi tubuh kelihatan langsing .

\section{METODE PENELITIAN}

Penelitian ini dilaksanakan pada Bulan Maret - Juli 2019 Lokasi ditempat Puskesmas dalam Kota Baubau yaitu Puskesmas Meo-Meo, Puskesmas Katobengke, Puskesmas Sulaa, Puskesmas melai dan Puskesmas Waborobo. Penelitian ini menggunakan desain Quasi Experimental dengan rancangan yang digunakan pre-post test only with control group design, dalam penelitian ini menggunakan kelompok Intervensi (mengonsumsi ramuan tradisional Lancau Wolio), kelompok kontrol (tidak mengonsumsi ramuan tradisional Lancau Wolio).

Populasi dalam penelitian ini adalah seluruh ibu nifas yang melahirkan pada bulan maret sampai Juli di Puskesmas Meo-Meo, Puskesmas Katobengke, Puskesmas Sulaa, Puskesmas Melai dan Puskesmas Waborobo. Pengambilan sampel dengan teknik accidental sampling yang 
Journal of Healthcare Technology and Medicine Vol. 6 No. 2 Oktober 2020

Universitas Ubudiyah Indonesia

e-ISSN : 2615-109X

memenuhi kriteria inklusi dan eksklusi sebanyak 40 ibu yang terbagi atas kelompok intervensi 20 ibu dan kelompok kontrol $20 \mathrm{ibu.}$

Pengukuran involusio uteri dengan pemeriksaan ultrasonografi (USG) dan pengukuran estetika kecantikan dengan penimbangan berat badan sebelum dan setelah dua minggu mengonsumsi Lancau Wolio.

Untuk menguji data berdistribusi normal/tidak menggunakan uji statistik kolmogorovsmirnov. Taraf signifikan $(\alpha=0,05)$. Jika $\alpha>0,05$, maka Ho diterima yaitu data berdistribusi normal. Jika data berdistribusi normal, uji analisis menggunakan ujipaired $t$ testdanujiindependent paired t testjika data tidak berdistribusi normal menggunakan uji kruskal wallis.

\section{HASIL DAN PEMBAHASAN}

\section{HASIL}

A. Perubahan Involusio Uterus

Tabel 1. Distribusi perubahan involusio uterus berasarkan diameter rahim sebelum dan sesudah intervensi

\begin{tabular}{|l|l|c|c|c|c|c|c|}
\hline \multirow{2}{*}{ No } & \multirow{2}{*}{ Kelompok } & \multicolumn{2}{|c|}{ pretest } & \multicolumn{4}{c|}{ Post test 1} \\
\cline { 3 - 8 } & \multirow{3}{*}{1} & \multicolumn{2}{|c|}{$>5 \mathrm{~cm}$} & \multicolumn{2}{c|}{$>5 \mathrm{~cm}$} & \multicolumn{2}{c|}{$<5 \mathrm{~cm}$} \\
\cline { 3 - 8 } 1 & Intervensi & $\mathrm{n}$ & $\%$ & $\mathrm{n}$ & $\%$ & $\mathrm{n}$ & $\%$ \\
\cline { 3 - 8 } 2 & Kontrol & 20 & 100 & 4 & 20 & 16 & 80 \\
& & 20 & 100 & 3 & 15 & 17 & 85 \\
\hline
\end{tabular}

Tabel 1 menunjukan bahwa pada saat pretest diketahui semua sampel memiliki diameter rahim $>5 \mathrm{~cm}$ dan setelah perlakuan selama 2 minggu atau post test menunjukan hasil penurunan diameter rahim pada kelompok intervensi yaitu 16 orang yang memiliki diameter rahim $<5 \mathrm{~cm}$ dan 4 orang juka mengalami penurunan diameter rahim tetapi masih $>5 \mathrm{~cm}$, pada kelompok kontrol terdapat 17 orang yang mengalami penurunan diameter rahim $<5 \mathrm{~cm}$ dan terdapat 3 orang yang mengalami penurunan tetapi masih dalam kategori $>5 \mathrm{~cm}$.

Tabel 2. Distribusi perubahan involusio uterus berasarkan panjang rahim sebelum dan sesudah intervensi

\begin{tabular}{|l|l|l|l|l|l|l|l|}
\hline \multirow{2}{*}{ No } & \multirow{2}{*}{ Kelompok } & \multicolumn{2}{|c|}{ pretest } & \multicolumn{4}{|c|}{ Post test } \\
\cline { 3 - 8 } & \multicolumn{2}{|c|}{$>7,5 \mathrm{~cm}$} & \multicolumn{2}{|c|}{$>7,5 \mathrm{~cm}$} & \multicolumn{2}{|c|}{$<7,5 \mathrm{~cm}$} \\
\cline { 3 - 8 } & $\mathrm{n}$ & $\%$ & $\mathrm{n}$ & $\%$ & $\mathrm{n}$ & $\%$ \\
\hline
\end{tabular}


Journal of Healthcare Technology and Medicine Vol. 6 No. 2 Oktober 2020

Universitas Ubudiyah Indonesia

e-ISSN : 2615-109X

\begin{tabular}{|l|l|c|c|c|c|c|c|}
\hline 1 & Intervensi & 20 & 100 & 6 & 30 & 14 & 70 \\
2 & Kontrol & 20 & 100 & 14 & 70 & 6 & 30 \\
\hline
\end{tabular}

Tabel 2 menunjukan bahwa pada saat pretest diketahui semua sampel memiliki panjang rahim $>7,5 \mathrm{~cm}$ dan setelah perlakuan selama 2 minggu atau post test menunjukan hasil penurunan panjang rahim pada kelompok intervensi yaitu 14 orang yang memiliki diameter rahim $<7,5 \mathrm{~cm}$ dan 6 orang juga mengalami penurunan panjang rahim tetapi masih dalam kategori $>7,5 \mathrm{~cm}$, pada kelompok kontrol terdapat 6 orang yang mengalami penurunan diameter rahim $<7,5 \mathrm{~cm}$ dan terdapat 14 orang yang mengalami penurunan tetapi masih dalam kategori $>7,5 \mathrm{~cm}$.

Tabel 3. Perubahan diameter Uterus Sebelum dan Setelah Intervensi pada Masing-masing Kelompok

\begin{tabular}{|l|l|l|l|l|l|l|}
\hline No & Kelompok & pretest & \multicolumn{5}{|c|}{ Post test } \\
\hline & & Mean \pm SD & Mean \pm SD & Beda \pm SD & \%penurunan & P \\
1 & intervensi & $7.51 \pm 1.13$ & $5.71 \pm 1.39$ & $1.81 \pm 1.45$ & 31.70 & 0.000 \\
2 & kontrol & $6.68 \pm 0.92$ & $4.77 \pm 0.64$ & $1.91 \pm 1.01$ & 40.04 & 0.000 \\
\hline
\end{tabular}

Tabel 3 menunjukan penurunan rata-rata diameter uterus berdasarkan hasil pemeriksaan USG setelah dua minggu perlakuan atau post-test palinggi pada kelompok kotrol yaitu dengan penurunan sebesar 40,04\% dan kelompok intervensi menunjukan penurunan diameter uterus $31,70 \%$, hasil uji statistik menunjukan bahwa kelompok intervensi dan kelompok kontrol signifikan masing-masing diperoleh nilai $p 0,000(p>0,05)$ artinya ada perbedaan diameter uterus sebelum intervensi dan setelah intervensi pada masing-masing kelompok.

Tabel 4. Perubahan panjang Uterus Sebelum dan Setelah Intervensi pada Masing-masing Kelompok

\begin{tabular}{|c|c|c|c|c|c|c|}
\hline No & Kelompok & pretest & \multicolumn{4}{|c|}{ Post test } \\
\hline $\begin{array}{l}1 \\
2\end{array}$ & $\begin{array}{l}\text { intervensi } \\
\text { kontrol }\end{array}$ & $\begin{array}{l}\text { Mean } \pm \text { SD } \\
10.49 \pm 1.01 \\
10.34 \pm 0.75\end{array}$ & $\begin{array}{l}\text { Mean } \pm \text { SD } \\
7.42 \pm 0.84 \\
8.18 \pm 0.71\end{array}$ & $\begin{array}{l}\text { Beda } \pm \text { SD } \\
3.07 \pm 1.04 \\
2.14 \pm 0.93\end{array}$ & $\begin{array}{l}\text { \%penurunan } \\
41.37 \\
26.16\end{array}$ & $\begin{array}{l}\mathrm{P} \\
0.000 \\
0.000\end{array}$ \\
\hline
\end{tabular}


Journal of Healthcare Technology and Medicine Vol. 6 No. 2 Oktober 2020

Universitas Ubudiyah Indonesia

e-ISSN : 2615-109X

Tabel 4 menunjukan penurunan rata-rata panjang uterus berdasarkan hasil pemeriksaan USG setelah dua minggu perlakuan atau post-test tertinggi pada kelompok intervensi

\begin{tabular}{|c|c|c|c|c|c|c|c|}
\hline & No & Kelompok & pretest & \multicolumn{4}{|c|}{ Post test } \\
\hline penurunan & & & Mean \pm SD & Mean \pm SD & Beda \pm SD & \%penurunan & $P$ \\
\hline sebesar & 1 & intervensi & $60,4 \pm 6,53$ & $56,4 \pm 6.28$ & $4,00 \pm 7,80$ & 7,09 & 0.000 \\
\hline $41.37 \%$ dan & 2 & kontrol & $58,8 \pm 4.27$ & $56,8 \pm 4,38$ & $2.00 \pm 1,43$ & 3,52 & 0.000 \\
\hline
\end{tabular}

kelompok

kontrol menunjukan penurunan panjang uterus $26,16 \%$, hasil uji statistik menunjukan bahwa kelompok intervensi dan kelompok kontrol signifikan masing-masing diperoleh nilai $p$ 0,000 $(p>0,05)$ artinya ada perbedaan tinggi uterus sebelum intervensi dan setelah intervensi pada masing-masing kelompok.

Tabel 5. Perubahan Berat Badan Sebelum dan Setelah Intervensi pada Masing-masing Kelompok

Tabel 5 menunjukan penurunan rata-rata berat badan setelah dua minggu perlakuan atau post-test tertinggi pada kelompok intervensi yaitu dengan penurunan sebesar 7,09\% dan kelompok kontrol menunjukan penurunan berat badan 3,52\%, hasil uji statistik menunjukan bahwa kelompok intervensi dan kelompok kontrol signifikan masing-masing diperoleh nilai $p$ $0,000(p>0,05)$ artinya ada perbedaan berat badan sebelum intervensi dan setelah intervensi pada masing-masing kelompok.

Tabel 6. Rata-rata diameter uterus antara kelompok intervensi dan Kelompokkontrol

\begin{tabular}{|c|l|c|c|}
\hline Tinggi uterus & \multicolumn{1}{|c|}{ Kelompok } & Mean \pm SD & $\mathrm{p}$ \\
\hline posttest & Intervensi & $5,71 \pm 1,39$ & 0,010 \\
& & $4,77 \pm 0,64$ & \\
\hline
\end{tabular}

Tabel 6 menunjukan bahwa hasil uji statistic diketahui nilai p $0,010<\alpha 0,05$ yang artinyya ada perbedaan diameter uterus antara kelompok intervensi dan kelompok kontrol 
Journal of Healthcare Technology and Medicine Vol. 6 No. 2 Oktober 2020

Universitas Ubudiyah Indonesia

e-ISSN : 2615-109X

setelah dua minggu pelakuan, dengan nilai ratarata diameter uterus terendah ada kelompok control yaitu 4,77 dan kelompok intervensi 5,71.

Tabel 7. Ratarata panjang uterus antara kelompok intervensi dan kelompok kontrol

\begin{tabular}{|c|l|c|c|}
\hline diameter uterus & \multicolumn{1}{|c|}{ Kelompok } & Mean \pm SD & p \\
\hline posttest & Intervensi & $7,41 \pm 0,84$ & 0,004 \\
& kontrol & $8,18 \pm 0,71$ & \\
\hline
\end{tabular}

Tabel 7 menunjukan bahwa hasil uji statistic diketahui nilai p 0,004< $<0,05$ yang artinyya ada perbedaan panjang uterus antara kelompok intervensi dan kelompok kontrol setelah dua minggu pelakuan, dengan nilai ratarata panjang uterus terendah ada kelompok intervensi yaitu 7,41 dan kelompok kontrol 8,18.

Tabel 8. Ratarata berat badan antara kelompok intervensi dan kelompok kontrol

\begin{tabular}{|c|l|c|c|}
\hline Beratbadan & \multicolumn{1}{|c|}{ Kelompok } & Mean \pm SD & p \\
\hline posttest & Intervensi & $56,4 \pm 6,28$ & 0,812 \\
& kontrol & $56,8 \pm 4,38$ & \\
\hline
\end{tabular}

Tabel 8 menunjukan bahwa hasil uji statistic diketahui nilai p 0,812> 0,05 yang artinya tidak ada perbedaan berat badan antara kelompok intervensi dan kelompok kontrol setelah dua minggu pelakuan, dengan nilai ratarata berat badan kelompok intervensi yaitu 56,4 dan kelompok kontrol 56,8.

\section{PEMBAHASAN}

\section{Perubahan Involusio Uterus}

Ramuan tradisional Lancau Wolio yang biasa digunakan masyarakat buton pasca melahirkan. Lancau Wolio memanfaatkan akar, batang, dan umbi dari 40 jenis tanaman beberapa jenis tanaman seperti alang-alang, kayu jawa, sambung nyawa, paku uban, waru, patah tulang, adem ati, dan daun pacar yang diklaim masyarakat Baubau dapat membantu proses Involusio Uterus dengan membantu proses penyembuhan luka dalam, memperlancar pengeluaran darah pasca melahirkan. Selain digunakan sebagai ramuan pasca melahirkan Lancau Wolio juga biasa dikonsumsi masyarakat sebagai penurun tekanan darah. Penelitian 
Journal of Healthcare Technology and Medicine Vol. 6 No. 2 Oktober 2020

Universitas Ubudiyah Indonesia

e-ISSN : 2615-109X

Lancau Wolio terhadap involusio uteri belum pernah dilakukan sebelumnya. Namun beberapa penelitian tentang Involusio Uteri pernah dilakukan sebelumnya.

Konsumsi lancau wolio pasca melahirkan dapat membantu proses involusio uteri, hal ini disebabkan karena ramuan Lancau wolio memiliki beberapa tanaman yang dapat membantu proses pemulihan luka dalam dan memperlancar pengeluaran darah pasca melahirkan seperti alang-alang, kayu jawa, sambung nyawa, paku uban, waru, patah tulang, adem ati, dan daun pacar.

Namun pada kelompok kontrol terdapat pula penurunan involusio uteri terutama pada diameter lebar uterus lebih cepat menurunannya dibandingkan kelompok intervensi. Hal ini dipengaruhi oleh mobilisasi dini dan inisiasi menyusu dini. Mobilisasi dini merupakan salah satu faktor penting yang harus dilakukan ibu untuk mempercepat proses pemulihan pasca bersalin yakni dengan miring kanan miring kiri, duduk, berdiri dan berjalan. Menurut Manuaba (1999) mobilisasi dini atau aktivitas segera dilakukan setelah beristirahat beberapa jam dan beranjak dari tempat tidur ibu pada persalinan normal. Mobilisasi dini dapat mengurangi bendungan lochea dalam rahim, meningkatkan peredaran darah sekitar alat kelamin, mempercepat normalisasi system reproduksi dalam keadaan semula.

Inisiasi menyusu dini, dimana proses yang terjadi pada waktu bayi menghisap, otot-otot polos pada puting susu teregang dan terangsang, rangsangan ini diteruskan ke otak oleh saraf. Kemudian otak memerintahkan kelenjar hipofise anterior mengeluarkan prolactin untuk payudara memproduksi ASI dan kelenjar hipofisis posterior mengeluarkan hormon oksitosin yang dibawa ke otot-otot pada mamae, sehingga otot-otot polos pada mammae berkontraksi, selain itu hormon oksitosin mempengaruhi otot-otot polos pada uteri sehingga berkontraksi sangat baik sehingga involusi uteri lebih cepat dan pengeluaran lochea lebih lancer (Saifuddin, 2002).

Hal ini sejalan dengan penelitian Yusro hadi dan Martini Fairus (2012) tentang "faktorfaktor yang berhubungan dengan involusio uterus di Lampung Utara" yang menyatakan bahwa mobilisasi dini dan inisiasi menyusu dini berhubungan erat dengan involusio uterus sedangkan umur dan paritas tdk berhubungan dengan involusio uterus.

\section{Estektika Kecantikan (Berat Badan)}

Ramuan tradisional Lancau Wolio diklaim oleh masyarakat wolio di kota baubau dapat menurunkan berat badan dan memberi efek kesegaran pada badan. Ramuan tradisional Lancau wolio selain dikonsumsi oleh ibu nifas juga biasa dikonsumsi oleh para gadis wolio dengan 
Journal of Healthcare Technology and Medicine Vol. 6 No. 2 Oktober 2020

Universitas Ubudiyah Indonesia

e-ISSN : 2615-109X

tujuan untuk menurunkan berat badan bagi mereka yang memiliki berat badan berlebih dan juga diklaim dapat meningkatkan berat badan bagi mereka yang memiliki berat badan kurang. Beberapa kandungan ramuan tradisional Lancau Wolio yang diklaim dapat meningkatkan berat badan yaitu Asam jawa, jarak, gingseng jawa. Sedangkan kandungan ramuan tradisional Lancau Wolio yang diklaim dapat meningkatkan nafsu makan yaitu brotowali, cendana, rotan, meniran.

Menurut Indriati (2009) dengan memperhatikan kualitas dan kuantitas ASI serta keadaan tubuh ibu, maka ibu nifas dapat menurunkan berat badan $1 \mathrm{~kg}$ dalam 1 minggu. Menurut Christian (2007) dalam Brace Carol Sipasulta (2010) ibu nifas akan kehilangan berat badan selama 6 bulan sebanyak $11 \mathrm{~kg}$ hanya dengan memberikan ASI Eksklusif. Hal ini disebabkan karena tubuh ibu memerlukan tenaga sebanyak 500 kalori setiap hari untuk menghasilkan ASI yang dibutuhkan selama menyusui bayinya sehingga dalam seminggu ibu yang menyusui bayinya secara eksklusif akan kehilangan tenaga sebanyak 3.500 kalori atau $0,45 \mathrm{~kg}$ berat badannya untuk menyediakan ASI sebagai makanan bagi bayinya.

Penelitian yang dilakukan oleh Brace Carol Sipasulta (2010) tentang “Analisis Faktorfaktor yang Berhubungan dengan Penurunan Berat Badan Ibu Post Partum di Kecamatan Balikpapan Selatan” menyatakan bahwa ibu yang memberikan ASI Eksklusif berpeluang 28.244 kali terjadi penurunan berat badan dibandingkan ibu yang tidak memberikan ASI eksklusif.

Sehingga dapat disimpulkan bahwa walaupun ibu tidak mengonsumsi obat tradisional Lancau Wolio akan tetap mengalami penurunan berat badan dengan menyusui bayinya secara eksklusif. Berdasarkan hasil observasi selama penelitian semua responden menyusui bayinya secara eksklusif. Namun berdasarkan hasil penelitian yang memiliki penurunan badan terbanyak adalah pada kelompok yang mengonsumsi ramuan tradisional Lancau Wolio.

\section{KESIMPULAN}

Ada efek pemberian ramuan tradisional Lancau Wolio terhadap involusio uterus terutama pada penurunan panjang uterus pada ibu nifas sedangkan untuk penurunan diameter uterus juga mengalami penurunan yang signifikan namun lebih besar persentase penurunan diameter uterus pada kelompok control. Sedangkan untuk estetika kecantikan dalam hal ini berat badan ibu nifas berdasarkan hasil uji statistic tidak ada perbedaan antara berat badan 
Journal of Healthcare Technology and Medicine Vol. 6 No. 2 Oktober 2020

Universitas Ubudiyah Indonesia

e-ISSN : 2615-109X

pretest dan post test tetapi ada penurunan berat badan yakni 7,09\% pada kelompok intervensi dan 3,52\% pada kelompok kontrol .

\section{SARAN}

Diharapkan hasil penelitian ini dapat dijadikan sebagai referensi masyarakat khususnya ibu nifas dalam memilih obat tradisional sebagai salah satu metode dalam pengobatan masa nifas. Dan untuk penelitian selanjutnya diharapkan data mengembangkan penelitian tentang obat trasidional lancau dengan 44 jenis tanaman yang salah satu kegunaannya dapat menurunkan tekanan darah.

\section{DAFTAR PUSTAKA}

1. Adwiyah, Rabiatul. 2017. Analisis kadar saponin ekstrak metanol kulit batang kemiri (aleurites moluccana (l.)Willd) dengan metode gravimetri. Skipsi Strata I. Fakultas Kedokteran dan Ilmu Kesehatan Masyarakat. Universitas Islam Negeri Aladdin Makassar, Makassar.

2. Afreni, M., Amaliani, T., Rizaldi, Rahanto, S., 2014, Kesembuhan Mulia Mamoh, Etnik Aceh Kabupaten Aceh Barat, Buku Seri Etnografi Kesehatan, Jakarta, LPB.

3. Agoes, Azwar, 2011, Tanaman Obat Indonesia, Salemba Medika, Jakarta.

4. Aksara, Riska, 2013. Identifikasi Senyawa Alkaloid Dari Ekstrak Metanol Kulit Batang Mangga (Mangifera Indica L.), 8(1), hal. 510-515

5. Ambarwati, Eny Retna; Diah Wulandari.2009. Asuhan Kebidanan Nifas. Yogyakarta: Mitra Cendikia

6. B2P2TOOT, 2017, Riset Khusus Eksplorasi Pengetahuan Lokal Etnomedisin Dan Tumbuhan Obat Berbasis Komunitas Di Indonesia, Jakarta, Kementrian Kesehatan Republik Indonesia.

7. Fitri, Nur Lailatul, 2016, pengaruh ekstrak buah ciplukan (physalis angulata l.) Terhadap kadar spgt dan sogt mencit putih jantan (Mus musculus). Jurnal Pendidikan Biologi Indonesia, 2 (2), hal. 180-187.

8. Hendri Wasito, 2011. Obat Tradisional Kekayaan Indonesia. Yogyakarta : Graha Ilmu

9. Hidayat, Rina Pratiwi, 2014. Potensi Kapuk Randu (Ceiba Petandra Gaertn) Dalam Penyediaan Obat Herbal. E-Journal Widya Kesehatan dan Lingkungan, 1 (1), hal. 53-60.

10. Indriati, M.T. (2009). Langsing dan Sehat Setelah Melahirkan Ala Selebriti. Genius Publisher. Yogyakarta

11. Ismarani, diah, dkk, 2014. Formulasi Gel Pacar Air (Impatiens balsamina Linn.) terhadap Propionibacterium acnes dan Staphylococcus epidermis. Jurnal Medical International, 1 (1), hal.

12. Karahap, Angga D, 2016. Uji efek antibakteri ekstrak batang akar kuning (arcangelisia flava merr.) Terhadap bakteri sthaphylococcus aureus dan escherichia coli. Jurnal e-Biomedik, 4 (1), Hal 661-670. 
13. Kartika, Rudi, 2016. Pengaruh pemberian ekstrak etanol daun kecapi (sandoricum koetjape (burm.f.) Merr.) Terhadap penurunan kadar kolesterol total pada mencit jantan (mus musculus). Jurnal Kimia Mulawarman, 13 (2), hal. 64-67

14. Latief, Abdul, 2013, Obat Tradisional, Jakarta : EGC

15. Listiawati, Yeni, 2010. Uji efek antipiretik ekstrak etanol daun legundi (vitex trifolia linn) pada kelinci yang diinduksi vaksin dpt-hb. Skripsi Strata I. Fakultas Farmasi, Universitas Muhammadiyah Surakarta, Surakarta.

16. Lungu, Marten, 2010. Pemanfaatan Rotan Oleh Suku Dayak Merap Di Desa Gong Solok Kecamatan Malinau Selatan Kabupaten Malinau. Skipsi Strata I . Jurusan Manajemen Hutan. Politeknik Pertanian Negeri Samarinda, Samarinda.

17. Lusiana, Kesi, dkk, 2013, aktivitas antibakteri dan kandungan fitokimia ekstrak daun waru lengis (hisbiscus tillaceus l.) Sebagai bahan dasar pembuatan sampo. Jurnal Biokimia, 5 (5), hal. 631-638

18. Mary,Kristhin Pabesak,2018.Etnomedisin Lancau Wolio Pada Perawatan Masa Nifas Perempuan Buton Di Kecamatan Murhum Kota Baubau. Karya Tulis Ilmiah. Jurusan DIII Kebidanan. PoliteknikBaubau.

19. Murni, dkk, 2014. Efektivitas ekstrak etanol daun ketepeng (cassia alata 1.) Dan ketepeng kecil (cassia tora 1.) Terhadap plasmodium falciparum secara in vitro. Jurnal Balaba, 10 (2), hal. 83-88.

20. Notoatmodjo, 2013, Promosi Kesehatan Dan Ilmu Perilaku, Jakarta: Rineka Cipta.

21. Pelealu, Delano, dkk, 2015. Pengaruh Jamu Dengan Tribulus Terrestris TerhadapKualitas Sperma Tikus Wistar Jantan (Rattus norvegicus). Jurnal eBiomedik (eBm),3 (2), Hal. 661-665.

22. Pratama, Aditya Bagus, Firzatullah Dwiko Ramadhan, 2013, Khasiat Tanaman Obat Herbal, Surabaya, Pustaka Media.

23. Pratiwi, Ratih Dyah, 2016. Uji aktivitas anti bakteri gel sariawan dari ekstrak daun saga (abrus precatorius linn.) Terhadap bakteri staphyloccocus aureus. Jurnal Ilmiah Manuntung, 2 (2), hal. 239-247.

24. Prawirohardjo,Sarwono, 2013, Pelayanan Kesehatan Maternal Dan Neonatal, Jakarta : PT Bina Pustaka Sarwono Prawirohardjo

25. Prawirohardjo, Sarwono. 2002. Buku Acuan Nasional Pelayanan Kesehatan Maternal Dan Neonatal. Jakarta: Tridasa Printer. Jakarta: Yayasan Bina Pustaka Sarwono Prawirohardjo.

26. Puspita, Sari Endah, dkk, 2009. Uji sitoksisitas ekstrak metanol buah buni (antidesma bunius (l.) Spreng) terhadap sel hela. Jurnal Ilmu Dasar, 10 (2), hal. 181185.

27. Rahimsyah, AR., 2012, Penyembuhan Alami Dengan Herbal Dan Pijat Refleksi, Surabaya, Dua Media.

28. Rahmi, dkk, 2011. Potency Of Java Talinum, Paniculatun Gaertn). Jurnal Kesehatan, 11 (1), hal 235-240.

29. Sabuding, Miss Amanee, 2018. Ujiaktivitas antidiabetes ekstrak etanol bunga kertas (bougainvillea spectabilis wild.) Pada tikus wistar yang diinduksi aloksan. Skripsi Strata I. Program Studi Farmasi. Universitas Muhammadiyah Surakarta, Surakarta.

30. Sembiring, HELMINA Br., dkk, 2016. Aktivitas Antioksidan Senyawa Flavonoida Dari Daun Benalu Kakao (Dendropthoe pentandra (L.) Miq.). Jurnal Chimica et Nature Acta, 4 (3), hal. 117-122. 
31. Sipasulta, Grace Carol. 2010. Analisis Faktor-faktor yang Berhubungan dengan Penurunan Berat Badan Ibu Post Partum di Kecamatan Balikpapan Selatan. FIK UI. Jakarta

32. Siti saleha, 2009. Asuhan Kebidanan Pada Masa Nifas, Jakarta : Salemba Medika

33. Sulistyowati, Ari. 2009. Buku Ajar Asuhan Kebidanan Pada IbuNifas. Yogyakarta: Andi

34. Sulistiawati, Ni Made, 2015. Ekstrak Kulit Batang Kusambi, Schleiscera olesa (oles), Jurnal kesehatan, Politeknik Baubau, Baubau Susilowati, Bau andi, 2014, pengaruh getah tanaman jarak pagar (jathropa curcas 1.) Terhadap daya hambat bakteri (staphyloccus), Jurnal Kesehatan, Politeknik Baubau, Baubau.

35. Sundu, Reksi, dkk, 2018. Uji Aktivitas Anti bakteri Ekstrak Etanol Umbi Paku Atai Merah (Angiopteris ferox Copel) TERHADAPPropioni bacterium acnes. Jurnal Medical Sains, 2 (2), hal. 75-82.

36. Suparni, Ari Wulandari, 2013, Herbal Nusantara, Yogyakarta : Andi Publisher

37. Varney, Helen. 2004. Ilmu Kebidanan (Varney's Midwife '3rd ed). Bandung :

Sekeloa Publisher

38. Vitria, Vanis, 2016. Pengaruh Ekstrak Ranting Dan Daun Tumbuhan Patah Tulang (Euphorbia Tirucalli) Terhadap Mortalitas Ulat Grayak (Sdoptera Litura) Instar Ii Secara In Vitro Sebagai Bahan Ajar Biologi. Skripsi Strata I. Program Studi Pendidikan Biologi. Universitas Muhammadiyah Malang, Malang.

39. Waluyo, Joko, 2014. Perbedaan daya hambat ekstrak daun kepuh (sterculia foetida l.) Dan jarak pagar (jatropha curcas l.) Terhadap pertumbuhan propioni bacterium acne. Junal Saintifika, 16 (1), hal. 10-17.

40. Walyani, E, S., Wahyuni, A., 2015, Asuhan Kebidanan Kegawatan Maternal Dan Neonatal, Pustaka baru pres.

41. Wirastuty, Resky Yalastri, 2016. Uji Efektifitas Gel Ekstrak Etanol Kulit Batang Kayu Jawa (Lannea Coromandelica) Pada Kelinci (Oryctolagus Cuniculus) Sebagai Obat Penyembuhan Luka Bakar, 1 (1), hal. 32-35

42. Yusro Hadi \& Martini Fairus. 2012. Faktor-faktor yang Berhubungan dengan Involusio Uterus pada Ibu Post Partum Di Wilayah Kerja Puskesmas Ketapang Lampung Utara. Jurnal Kesehatan Metro Sai Wawai. Tanjung karang. 